\title{
Plant biotechnology: a tool for development in Africa
}

\author{
Johan A. Brink \\ Director, UNESCO/BAC, BETCEN, ARC Roodeplaat, P/Bag X293, Pretoria, Republic of South Africa \\ Barbara R.Woodward \\ Research Officer, ARC Roodeplaat, P/Bag X293, Pretoria, Republic of South Africa \\ Edgar J. DaSilva ${ }^{1}$ \\ Director, Life Sciences Section, UNESCO, 1 rue Miollis, 75732 Paris cedex 15, France \\ E-mail: e.dasilva@unesco.org
}

\begin{abstract}
Africa is, paradoxically, a continent rich in resources, and yet, lacking and lagging in overall development. When the wealth of Africa's people is compared with that of other continents a contrasting picture of poverty, stunted growth and famine resulting from inadequate food production is revealed. The agricultural, and food security problems in Africa cannot be solved by applying plant biotechnology alone. Five key factors seem to be necessary for the improvement of crop production such as the use of agrochemicals, irrigation, plant breeding, farm management, and, of course, plant biotechnology. In this context, biotechnology can play a role in commercializing crops, creating new jobs and earning foreign exchange. The goals of national and regional development in Africa are attainable through proper planning and active participation in technical networks involving regional and international scientific cooperation that emphasize the use of plant and microbial genetic resources for economic development and progress.
\end{abstract}

The current world population, approximately 5.8 billion, is expected to double by the year 2050 (James, 1997). The population increase in developing countries constitutes $97 \%$ of the global increase (Swaminathan, 1995), and it is estimated that by $2050,90 \%$ of the planet's population will reside in the developing countries of the southern hemisphere. The challenge for the future, therefore, lies in global food security that necessitates a doubling of food production in the next 50 years to meet the needs of the population (James, 1997).

Africa, a continent yet to fulfil its food production potential, is especially vulnerable in terms of food security. The continent's wealth of natural resources and indigenous technologies have not been used either for endogenous technical development nor economic advancement (Michaelis, 1993). During mid-1995, the population of Africa, with the fastest growth rate in the world, was 720 million, which constituted $13 \%$ of the world population. At the present rate of growth this number will double over the next 25 years (Nyira, 1995). This population expansion which puts a burden on economic growth, also decreases food security, and environmental sustainability. To meet Africa's food requirements, it is therefore necessary to increase the efficiency of food production. Africa has lagged behind in reaping the benefits of the "Green Revolution" of the 1970s and 1980s on account of the limited use of high-yielding varieties of maize, wheat and rice on the continent. Furthermore, five key factors are required for improved crop production viz., use of appropriate agrochemicals, sustainable irrigation, efficient high-yielding (adapted) varieties, crop management, and plant biotechnology. Notwithstanding public concerns, it is felt that the major increase in agricultural productivity will be achieved through the direct use of genetic improvement and biotechnology (Villalabos, 1995).

World-wide, the beneficial impact of plant biotechnology has been almost exclusively on crops of high economic importance such as maize, wheat, soybean, sunflower, rice and potato. Other species, important to the developing countries of Africa, however has not attracted the interest of the well-known multinational seed- and biotechnology companies due to their low socio-economic status and contribution to the national exchequer. The result is that genetic and biotechnological improvement of these "neglected" food species is confined to local and specialized research at specific crop centres within these countries.

There are serious limiting factors to research activities and the use of biotechnology in African countries. These include inadequate infrastructure, lack of skilled human resources and availability of research equipment and facilities (Villalobos, 1995). In this context, Africa, therefore, also risks missing the opportunity to benefit from the "gene revolution".

\footnotetext{
${ }^{1}$ Corresponding author
} 


\section{Status of plant biotechnology in Africa}

Despite the frustrating problems of communication across the African continent, and poor exchange of scientific information and research results, Massola (1992) attempted a review of plant biotechnologies practiced in Frenchspeaking Sub-Saharan Africa. Though substantial research only was being carried out in Burundi, Cameroon, Cote d'Ivoire, Congo, Gabon Rwanda, Senegal, Togo and Zaire, very few of these countries had reached the take-off stage in using large-scale micropropagation for the development of local and regional market-products. Development of plant biotechnology in these countries, nevertheless, is underpinned by established biotechnological centres, either of a regional or international character, that specialize in in vitro cultivation of cash crops e.g. banana, coffee, cocoa, palm-oil, vanilla, and food crops such as maize, millet, cassava and cowpea.

A literature-scan shows that there is a growing emergence of African biotechnological expertise that has been nurtured by several initiatives pioneered by $\mathrm{ORSTOM}^{1}, \mathrm{CIRAD}^{2}$, and the UNESCO-based BETCEN ${ }^{3}$ and MIRCENs ${ }^{4}$ in the Republic of South Africa, Senegal, Kenya and Egypt. The outputs of such initiatives are:
- Improvement of phytosanitary and quarantine conditions

- Cloning of in vitro plants of ornamental and economic significance

- Bioprospecting of new nitrogen fixing species of bacteria and mycorrhizae

- Increased creation of novel genetic and hybrid variability

- Diversification of bioindustrial production of plant metabolites of medical significance e.g. reserpine (Rauwolfia serpentina), glycyrhetic acid (Abrus precatorius), and rotenone (Tephrosia vogelii)

- Development of joint academic/industrial ventures e.g. Prosem, Vitropic, and Tropiclone that have been set up by CIRAD

- Development and release in South Africa of commercialised transgenic products such as yieldgard maize and bollgard cotton.

Table 1 summarizes the current range of status and trends in plant biotechnology that exists in English and Frenchspeaking

Africa.

- Production of quality-controlled biofertilizers

Table 1. Current African trends and status in plant biotechnology in Africa

\begin{tabular}{|c|c|c|}
\hline Region & Country & Area of Research \\
\hline \multirow{3}{*}{$\begin{array}{l}\text { North } \\
\text { Africa }\end{array}$} & Egypt & - Genetic engineering of potatoes, maize and tomatoes \\
\hline & Morocco & $\begin{array}{ll}\text { - } & \text { Micropropagation of forest trees, date palms } \\
\text { - } & \text { Development of disease-free and stress tolerant plants } \\
\text { - } & \text { Molecular biology of date palms and cereals } \\
\text { - } & \text { Field tests for transgenic tomato }\end{array}$ \\
\hline & Tunisia & $\begin{array}{l}\text { - Abiotic stress tolerance and disease resistance } \\
\text { - Genetic engineering of potatoes } \\
\text { - Tissue culture of date palms, Prunus rootstocks and citrus } \\
\text { - DNA markers for disease resistance }\end{array}$ \\
\hline \multirow[t]{3}{*}{ West Africa } & Burkina Faso & $\begin{array}{l}\text { - Biological nitrogen fixation, production of legume inoculants, fermented } \\
\text { foods, medicinal plants }\end{array}$ \\
\hline & Cameroon & $\begin{array}{l}\text { - Plant tissue culture of Theobroma cacao (cocoa tree), Hevea brasiliensis } \\
\text { (rubber tree), Coffea arabica (coffee tree), Dioscorea spp (yam) and } \\
\text { Xanthosoma mafutta (cocoyam) } \\
\text { Use of in vitro culture for propagation of banana, oil-palm, pineapple, cotton } \\
\text { and tea }\end{array}$ \\
\hline & Cote d'Ivoire & $\begin{array}{l}\text { - In vitro production of coconut palm (Cocos nucifera) and yam } \\
\text { - } \quad \text { Virus-free micropropagation of egg-plant (Solanum spp) }\end{array}$ \\
\hline
\end{tabular}




\begin{tabular}{|c|c|c|}
\hline & & - Production of rhizobial-based biofertilizers \\
\hline & Gabon & $\begin{array}{l}\text { - Large-scale production of virus-free banana, plantain and } \\
\text { cassava plantlets }\end{array}$ \\
\hline & Ghana & $\begin{array}{l}\text { - Micropropagation of cassava, banana/plantain, yam, pineapple and cocoa } \\
\text { - Polymerase Chain Reaction (PCR) facility for virus diagnostics }\end{array}$ \\
\hline & Nigeria & $\begin{array}{l}\text { - Micropropagation cassava, yam and banana, ginger } \\
\text { - Long term conservation of cassava, yam and banana, and } \\
\text { medicinal plants } \\
\text { - Embryo rescue for yam } \\
\text { - Transformation and regeneration of cowpea, yam, cassava } \\
\text { and Banana } \\
\text { - Genetic engineering of cowpea for virus and insect resistance } \\
\text { - Marker assisted selection of maize and cassava } \\
\text { DNA fingerprinting of cassava, yams, banana, pests, and } \\
\text { - Genobial pathogens } \\
\text { - Human resouge maps for cowpeas, cassava, yams and banana } \\
\text { degree related training, fellowships and networking }\end{array}$ \\
\hline & Senegal & $\begin{array}{l}\text { - Well established MIRCEN programme that serves the } \\
\text { region of West Africa in microbial-plant interaction } \\
\text { - Production of rhizobial and mycorhizal-based biofertilizers for rural markets } \\
\text { Well established in vitro propagation of Faidherbia albida, } \\
\text { Eucalyptus canaldulensis, Sesbania rostrate, Acacia senegal, in co-operation } \\
\text { with several international agencies }\end{array}$ \\
\hline \multirow[t]{5}{*}{\begin{tabular}{|l|} 
East \& \\
Central \\
Africa
\end{tabular}} & Burundi & $\begin{array}{l}\text { - In vitro production of ornamental plants - orchids, tissue } \\
\text { culture of medicinal plants, micropropagation of potato, } \\
\text { banana, cassava and yam } \\
\text { - Supply of disease-free in vitro plants }\end{array}$ \\
\hline & Congo & $\begin{array}{l}\text { - In vitro culture of spinach (Basella alba) } \\
\text { - Plant pathology - studies in controlling tomato rot due to } \\
\text { Pseudomonas solanacearum } \\
\text { - Bioprospecting of nitrogen-fixing species }\end{array}$ \\
\hline & $\begin{array}{l}\text { Congo, } \\
\text { Democratic } \\
\text { Republic }\end{array}$ & $\begin{array}{l}\text { - In vitro propagation of potato, soybean, maize, rice and } \\
\text { multipurpose trees, e.g. Acacia auriculiforius and } \\
\text { Leucaena leucocefhala } \\
\text { - Production of rhizobial-based biofertilizers in experimental } \\
\text { stage } \\
\text { - Tissue culture of medical plants, e.g. Nuclea latifolia, } \\
\text { Phyllanthus niruroides }\end{array}$ \\
\hline & Ethiopia & $\begin{array}{l}\text { - Tissue culture research applied to tef } \\
\text { - Micropropagation of forest trees }\end{array}$ \\
\hline & Gabon & $\begin{array}{l}\text { - Large-scale production of virus-free banana and plantain } \\
\text { (Musa spp) and cassava plantlets (Manihot esculenta) }\end{array}$ \\
\hline
\end{tabular}




\begin{tabular}{|c|c|c|}
\hline & Kenya & $\begin{array}{l}\text { - Production of disease free plants and micropropagation } \\
\text { of pyrethrum, bananas, potatoes, strawberries, sweet } \\
\text { potato, citrus, sugar cane } \\
\text { - Micropropagation of ornamentals (carnation, alstromeria, } \\
\text { gerbera, anthurium, leopard orchids) and forest trees } \\
\text { - In vitro selection for salt tolerance in finger millet } \\
\text { - Transformation of tobacco, tomato and beans } \\
\text { - Transformation of sweet potato with proteinase inhibitor gene } \\
\text { Transformation of sweet potato with Feathery Mottle } \\
\text { ABSis, Coat protein gene (Monsanto, ISAAA }{ }^{5}, \text { USAID }^{8} \text {, } \\
\text { - Tissue culture regeneration of papaya } \\
\text { - In vitro long term storage of potato and sweet potato } \\
\text { - Marker assisted selection in maize for drought tolerance } \\
\text { A nd insect resistance } \\
\text { - Well-established MIRCEN providing microbial biofertilizers in the East } \\
\text { African region }\end{array}$ \\
\hline & Rwanda & $\begin{array}{l}\text { - Production of rhizobial-based biofertilizers, and Azolla for } \\
\text { rice cultivation } \\
\text { - Tissue culture of medical plants and micropropagation of } \\
\text { disease-free potato, banana and cassava }\end{array}$ \\
\hline & Uganda & $\begin{array}{l}\text { Micropropagation of banana, coffee, cassava, citrus, } \\
\text { granadella, pineapple, sweet potato and potato } \\
\text { - In vitro screening for disease resistance in banana } \\
\text { - Production of disease free plants of potato, sweet potato } \\
\text { and banana }\end{array}$ \\
\hline \multirow[t]{3}{*}{$\begin{array}{l}\text { Southern } \\
\text { Africa }\end{array}$} & Madagascar & $\begin{array}{l}\text { - Tissue culture programme supporting conventional } \\
\text { production of disease-free rice and maize plantlets, and } \\
\text { Medicinal plants } \\
\text { - Production of biofertilizers to boost production of } \\
\text { groundnut (Arachis hypogea), bambara groundnut } \\
\text { - (Vigna subterranea) }\end{array}$ \\
\hline & Malawi & $\begin{array}{l}\text { - Micropropagation of banana, trees (Uapaca), tropical } \\
\text { woody species, tea }\end{array}$ \\
\hline & South Africa & $\begin{array}{l}\text { - Genetic engineering } \\
\text { - } \quad \text { Cereals: maize, wheat, barley, sorghum, millet, soybean, lupins, } \\
\text { sunflowers, sugarcane } \\
\text { - } \quad \text { Vegetables and ornamentals: potato, tomato, cucurbits, } \\
\text { ornamental bulbs, cassava and sweet potato } \\
\text { - } \quad \text { Fruits: apricot, strawberry, peach, apple, table grapes, banana } \\
\text { - Molecular marker applications } \\
\text { - } \quad \text { Diagnostics for pathogen detection } \\
\text { - } \quad \text { Cultivar identification - potatoes, sweet potato, ornamentals, cereals, } \\
\text { - } \quad \text { Sassava } \\
\text { - } \quad \text { Marker assisted selection in maize, tomato } \\
\text { - } \text { Markers for disease resistance in wheat, forestry crops } \\
\text { Tissue culture } \\
\text { - } \quad \text { Production of disease free plants - potato, sweet potato, cassava, dry } \\
\text { - } \text { beans, banana, ornamental bulbs } \\
\text { - Micropropagation of potato, ornamental bulbs, rose rootstocks }\end{array}$ \\
\hline
\end{tabular}




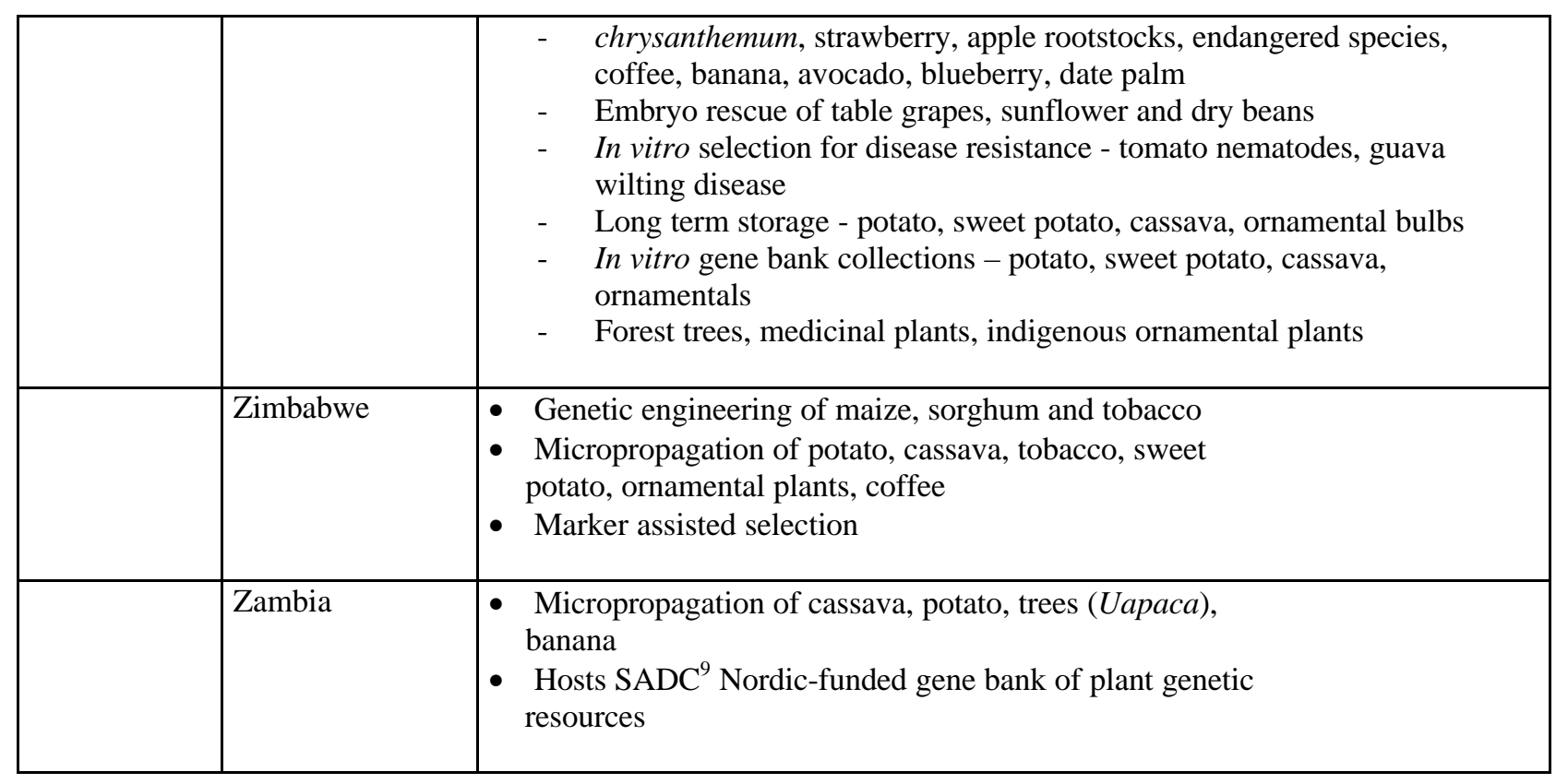

\section{Constraints}

Biotechnology is normally be defined as "any technique that uses living organisms, or substances from these organisms, to make or modify a product, to improve plants or animals, or to develop microorganisms for specific uses" (Persley, 1992). In plant biotechnology, three applications of broad fields of study such as plant tissue culture, genetic engineering and plant molecular markers can be identified. These applications range from the simple to the sophisticated, and in many cases are appropriate for use in Africa.

Investments in, and development of plant biotechnological research capacity in Africa is best accomplished in phases (Lynam, 1995). The first phase involves the use of plant tissue culture, which is appropriate for Africa as many of the important food crops such as cassava, sweet potato, yam and banana are vegetatively propagated. Specific techniques include in vitro mass propagation, the production of disease-free plants as well as regeneration systems for plant transformation. By focusing on tissue culture, the skills necessary to maintain and to manage a biotechnology laboratory can be developed. The second phase is the application of biotechnological tools, which can improve the efficiency of selection and breeding of varieties/cultivars. Techniques include more advanced tissue culture techniques (e.g. anther culture and embryo rescue) as well as molecular marker applications (diagnostics, fingerprinting and marker-assisted breeding). A prerequisite for this phase is to have an operational breeding programme in place. The third phase is the development of capacity to produce transgenic plants, which could include gene isolation and cloning, gene insertion/transformation, regeneration of transgenic plants as well as verification of successful transformation and gene function. The successful production of transgenic plants requires an adequate infrastructure, expertise in tissue culture and molecular biology, and a critical mass of researchers with supporting sustainable funding to cover the high cost of such research. Only a few laboratories in South Africa, Nigeria, and in Egypt have the capacity to produce transgenic plants, but still lack the ability to "commercialize" the product, or to ensure that these plants reach the end user, i.e. the African farmer. To bridge this gap, it is necessary to form partnerships with either seed companies, producer organisations or government institutions which can ensure that the sophisticated technology be delivered in the most well known and accepted technology known to farmers - the seed (James, 1996).

Constraints to the application of plant biotechnology in African countries are many. These are listed below:

\section{Lack of resources for plant biotechnology}

A serious deficit of skilled human resources in the plant sciences and biotechnology is evident in Africa. The building up of such knowledge and development of human resource capacity, is necessary to produce improved varieties through use of biotechnology as well as to handle imported engineered varieties that also demand changes in agricultural management. Another serious constraint is the loss of skilled personnel who have received training in developed countries and have added to the brain drain. Working opportunities in Africa are often inadequate. Funds to pay salaries and absorb running costs of projects are either limiting or inadequate thus contributing to reduced availability of personnel. Even specific focal 
research points that were created in Africa at high donor expense, lack the critical mass of skilled personnel. Furthermore, training gained abroad is often not attuned to local needs because of the different research and infrastructural environments in many African countries. As a result the demands and opportunities present in the home country are often not met or remain unanswered.

In several African countries, basic infrastructure and facilities even for the simplest tissue culture techniques such as micropropagation are not available. Modern communication systems, telephones, fax and access to email and Internet are also lacking in large areas of Africa which seriously hamper the acquisition of relevant and necessary knowledge, and the application of plant biotechnology which is a rapidly changing and developing field. Again, unreliable power supply in many African countries is a serious constraint for the efficient application of even basic tissue culture techniques. And the availability of chemicals and consumables for research is often hindered as a result of poor infrastructure.

\section{Selection of crops for research}

Crops utilized in Africa are often not important enough to attract foreign investment in research. Nevertheless, some important African crops such as cassava and sweet potatoes attract only extrabudgetary funding. On the other hand, indigenous neglected crops attract funding only for exploitation outside Africa. Finally, there is a telling lack of basic research on neglected or underutilized crops which includes aspects of crop grow, and plant protection.

\section{Lack of linkages and networks}

Information and communication technology in Africa is neither not available nor up to standard. Funding to run electronic communicative networks is limited. Finally, to overcome these constraints, networks should also include researchers from other continents other than Africa.

\section{Commercialized world crops are not so important in Africa}

Most of these crops are not well adapted to Africa, since imported lines or cultivars are inappropriate for local conditions. Furthermore, their cultivation is too expensive (premium to be paid), and have high energy input requirements. And again, these crops may be susceptible to local diseases and insects.

\section{Political/Legislature component}

A lack of (national/regional) priority setting in agricultural research is evident in many African countries which is reflected in a lack of awareness and commitment by the national governments. As a result, no specific policy or strategy can be formulated by the National Agricultural Research Centers in each country on the application of plant biotechnology. Research \& development programmes currently in place in Africa are often isolated, are not needdriven and have no definite objectives to develop specific products. Biosafety regulations and legislation are in place only in a few countries of Africa, and such limitation constitutes a serious constraint that impairs the use, evaluation and release of genetically modified organisms. Another concomitant issue is the lack of protection of intellectual property rights in Africa that hampers the development of new technologies, profitable inventions and investments, and initiatives by entrepreneurial African biotechnologists.

\section{General constraints}

Climate and weather characteristics in Africa often pose serious challenges to, particularly, tissue culture research. In many countries, the total absence of a viable public or private seed industry contributes to the absence of an appropriate channel for the transfer of products developed through plant biotechnology. Moreover, Africa's natural resources and lack of conservation of such resources are exploited without any returns to African countries. Also, products currently under development in Africa have been produced on an empirical basis rather than as a result of a full cost-benefit and impact assessment analysis that justifies investment.

\section{Networking, Associations and Training Opportunities in Africa}

Networking is an effective means for enhancing scientific co-operation and maximizing information exchange at the regional and continental level. Major networks dealing with plant biotechnology in sub-Saharan Africa are the African Association for Biological Nitrogen Fixation (AABNF), the International Society for Tropical Root Crops (ISTRC), the African Plant Biotechnology Network (APBnet), the African Biosciences Network (ABN) the MIRCENS in East and West Africa, the Cassava Biotechnology Network (CBN) and several other initiatives all of which encourage dialogue between farmers, scientists and decision-makers to benefit from biotechnology or biotechnological activities of relevance to national and regional needs.

As a means of building up reserves of skilled human resources in Africa, short-term fellowships of 3-months duration were awarded in the field of plant and allied environmental biotechnologies to 53 young researchers, inclusive of twelve women scientists, selected from a total of 130 applicants, and coming from Burundi, Cameroon, Central Africa Republic, Comoros, Congo, Côte d'Ivoire, Eritrea, Ethiopia, Gabon, Ghana, Kenya, Madagascar, Malawi, Mali, Mauritius, Nigeria, Rwanda, Senegal, Sierra Leone, South Africa, Tanzania, Togo, Uganda, and Zaire.

Host institutes providing such training within the framework of the UNESCO/Biotechnology Action Council Scheme were in Australia, Belgium, Burkina Faso, 
Cameroon, Canada, Côte d'Ivoire, Egypt, France, Germany, Israel, Japan, Kenya, Norway, Senegal, Singapore, South Africa, Switzerland, UK and USA.

Likewise, during the period 1992 - 1998, 82 short-term fellowships were awarded to young researchers, inclusive of twelve women scientists, and coming from Botswana, Burkina Faso, Cameroon, Cape Verde, Comoros, Côte d'Ivoire, Ghana, Guinee, Guinee-Bissau, Kenya, Madagascar, Mali, Namibia, Niger, Nigeria, Rwanda, Senegal, South Africa, Tanzania, Togo, Uganda, Zambia, and Zimbabwe, for study in the industrial, desert, environmental, medical, bioconversion, aquatic and marine biotechnologies, and microbial systematics and taxonomy, fermentation technology, and diagnostic virology, within the framework of the UNESCO global network of Microbial Resources Centres.

Host institutions providing such training were in Australia, Brazil, Canada, China, Egypt, France, Germany, Israel, Kenya, Senegal, Slovenia, UK, and USA.

APBnet, with some initial funding from UNESCO, was established in 1989 in Nairobi, Kenya with a co-ordinating office at IITA, in Ibadan, Nigeria, and subregional offices for West, Central, East, North and Southern Africa. The co-ordination office collected data on biotechnology manpower and assembled it in a directory first published in 1990.

The African Biosciences Network (ABN) is a co-operative mechanism linking biological institutions and bioscientists in sub-Saharan Africa in a common effort aimed at improving the level of the know-how and the applications of the biosciences throughout the region. The $\mathrm{ABN}$ is the African regional arm of the International Biosciences Networks (IBN), through which the expertise of the international scientific community is brought into close contact with the African Network. Moreover, the $\mathrm{ABN}$ is the result of one of the main recommendations of the international symposium on State of Biology in Africa held in Accra (Ghana) in 1981 under the initiative of UNESCO, the International Council of Scientific Unions (ICSU) and IBN with financial support from several international organizations amongst which were UNDP and the United Nations Fund for Science and Technology. An assessment of the state of biology on the continent during that symposium revealed that biological resources, especially latest developments, could contribute to solving problems of food production and famines, endemic diseases, irrational use of natural resources, conservation of biodiversity, and counteracting poverty and its consequences on people and their environment in Africa. The first phase (1983-86) of the tripartite ABN initiative deployed the networking process to link African biologists to one another and through ICSU, UNESCO and the IBN, to biologists in other countries and regions and, with other intergovernmental and non-governmental organizations working within the continent in related fields. In that 4year period, eleven research projects, eight training courses, workshops and conferences were organized and successfully implemented and 4 books (including the publication of a Directory of African Bioscientists) were published. About 650 scientists participated and contributed to the activities of the first phase. Research projects dealt with agroforestry, biocontrol of insect pests, basic immunology, epidemiological patterns in malaria and bilharzia, medicinal plants and protozoology. The highlevel short-term training courses dealt with specific topics in the sectors of forestry, insect pests, nutrition, endemic diseases, microbiology and biotechnology, and basic biology.

The second phase (1987-1992) of the African Biosciences network built upon the results of the proceeding phase with more emphasis on food production and endemic diseases. The programme comprised the following: - 91 research projects; 31 training courses, workshops, symposia and conferences; 25 travel grants and 9 publications. About 1000 African scientists participated in the second phase activities.

The main activities of member countries in the African Biosciences Network in the second phase were research projects carried out by two or more countries on a partnership basis; conferences; symposia; training courses, and workshops in the nine priority areas (Table 2).

Currently, the African Biosciences Network is engaged in capacity-building e.g. the training of young African scientists from Cameroon, Cote d'Ivoire and Senegal in Brazil, in the area of nitrogen-fixation and biofertilizer production.

Table 2. ABN member countries and priorities

\begin{tabular}{|l|l|l|}
\hline \multicolumn{2}{|c|}{ Regions } \\
\hline Central Africa & Eastern and Southern Africa & West Africa \\
\hline Burundi, Cameroon, & Angola, Botswana, Ethiopia, & Benin, Burkina Faso, \\
Central African Republic, & Equatorial Guinea, Kenya, Lesotho, & Cape Verde, Cote d'Ivoire, Ghana, \\
Chad, Congo, Gabon, & Malawi, Mozambique, Uganda, & Guinea Conakry, \\
Rwanda, Zaire & Swaziland & Liberia, Mali, Mauritania, Niger, \\
& & Nigeria, Senegal, Sierra Leone \\
\end{tabular}




\section{Priorities areas}

Animal breeding, endemic diseases, forest resources, insect pests, medicinal plants, microbiology, nutritional problems, ornamental plants breeding, water resources

The non-governmental association the African Association for Biological Nitrogen Fixation (AABNF), was founded in 1982 to promote scientific use of biological nitrogen fixation (BNF) in Africa, for purposes of increasing food production while reducing the need for purchased fertilizer inputs. BNF can help meet national goals of alleviating food shortage and malnutrition with improved quality of foodstuffs free of pollution hazards associated with mineral nitrogen fertilizers. The International Institute of Tropical Agriculture (IITA), Ibadan, within the IITA/UNDP project GLO/77/013 on "Maximizing Nitrogen Fixation by Cowpeas and Soybeans in Farming Systems in the Humid Tropics", and the Microbial Resources Centres (MIRCENs) in Kenya, Senegal and Egypt, played a central role in the founding of this multidisciplinary association of soil scientists, microbiologists, agronomists, climatologists, social economists, breeders, plant physiologists, biotechnologists, nutritionists and policymakers, among others interested in the promotion of BNF systems in Africa. Since 1984 the Association has organized seven conferences respectively in Kenya, Egypt, Senegal, Nigeria, Morocco, Zimbabwe and the Republic of South Africa to share experiences and information, to evaluate what has been done and to chart a course for the efficient exploitation of BNF systems in Africa, where the need to alleviate malnutrition and increase food production with minimal inputs is the most acute.

A major development problem facing a number of African countries is how to increase food production, which is invariably limited by the availability of nitrogen fertilizer. In Africa, the high capital costs of building chemical fertilizer plants prevents many African countries from manufacturing the quantities required to support a higher per-acre yield of food.

Considerable experience in the network approach has already been gained, especially through the MIRCENs for East and West Africa at the University of Nairobi and at the Centre National des Recherches Agronomiques, Bambey, Senegal. These MIRCENs functioned as the anchors of the networks within the framework of UNESCO's major regional project 1981 - 1985) in applied microbiology and biotechnology for Africa and the Arab States. Among the main mandates of the Nairobi MIRCEN are the collection, preservation, storage and distribution of authenticated microbial materials for deployment in environmental management through the Southern and Eastern African region, especially Kenya, Uganda, Tanzania, Malawi, Zambia and Zimbabwe, and elsewhere, and to serve as a taxonomic reference centre. Likewise, the West African
MIRCEN co-operates with research institutes in Mali, Sierra Leone, Gabon, Niger and Chad.

Culture collection, preservation and testing is one of the main services provided by the MIRCENs to the regions of East and West Africa. Since most of the collaborating laboratories are not very well equipped, culture identification, testing and preservation are generally carried out in Dakar and Nairobi with emphasis on Rhizobium. Authenticated cultures are lyophilized and conserved. Both local and imported Rhizobium strains are used for inoculant production for various grain, pasture and tree legumes. The trade name of inoculant produced by Nairobi MIRCEN is Biofix. All together inoculants were produced for 19 legume species. In recent years demand for inoculants has lagged behind total production and there is, therefore, need to expand the extension activities of the Nairobi MIRCEN. The Nairobi MIRCEN has a programme to educate farmers and agricultural extension officers on the merits arising from the proper use of inoculations produced by the MIRCEN in collaboration with the Kenya Seed Company. The catalytic roles of the MIRCENs in East, West and Southern Africa in harnessing. Biological-NitrogenFixation Technology (BNF) for boosting African Agriculture has recently been documented (Brink and Prior, 1998).

The Biotechnology Action Council (BAC) of UNESCO established a Biotechnology Education and Training Centre (BETCEN) for the African continent at the Roodeplaat Vegetable and Ornamental Plant Institute of the Agricultural Research Council (ARC) in Pretoria, South Africa in 1995. The main objective of the BETCEN for Africa is to provide short and medium term training in Plant Biotechnology to scientists of Africa. The BETCEN therefore also forms part of the BETCEN network that includes centres in Mexico (Latin and South America), Hungary (Eastern Europe), Bethlehem University, Palestine (Middle East) and Qingdao, China (Asia). This latter BETCEN specializes in marine biotechnology.

In the period November 1995 to September 1998, 16 courses were presented at the BETCEN at ARC-Roodeplaat in which 158 researchers from 23 countries participated. Furthermore, nine Fellowship candidates from seven African countries were attached to the BETCEN for training ranging from two to three months. BETCEN personnel have been in contact with many of the participants after their initial training and the feedback received regarding the application of techniques in their own institutes was very positive. The demand for training in basic biotechnology in Africa is very high and the emphasis in the future should be on the presentation of 
short specialized courses applied to specific African crops such as cassava, sweet potato or potato. Medium term training through fellowships (2-3 months) at ARCRoodeplaat will also serve a purpose in the sense that in depth training on a specific topic can be performed.

\section{Discussion}

The following recommendations are suggested for the successful implementation of Plant Biotechnology activities in developing countries:

- A National Biotechnology Policy Strategy should be formulated by the National Agricultural Research Centres of each country.

- With limited resources available demand driven plant tissue culture should be phased in.

- Opportunities in training of plant biotechnologists by the UNESCO/BAC BETCEN and IITA (short term and medium term training) as well as African Universities (long-term training) should be utilized.

- It should be ensured that available manpower is properly trained, that facilities and equipment are adequate, and that a critical mass of research personnel is available.

- Cooperation between universities, research institutions, the private sector and government agencies should be encouraged

- Biosafety regulations should be put into place to be able to benefit from the "gene revolution"

- The natural resources of each country should be developed and conserved by securing funds for basic crop research, protecting crops from exploitation, and conserving unique germplasm.

- Where possible, technology from developed countries should be utilized and adapted to local conditions.

- A country's own intellectual property rights should be protected along with the rights of other countries.

- Linkages between African countries as well as with the developed world should be stimulated through existing networks and joint projects.

\section{Concluding remarks}

Africa can benefit from previous experiences and results achieved in other developing regions in obtaining benefits from the applications of plant biotechnology. This can be done through proper planning, interactive cooperation among and between countries, and as network participants. Opportunities to conserve and develop the natural resources of Africa's wild relatives of commercial crops, neglected and underutilized crops, and plants with pharmaceutical applications should not be missed. This should be the primary focus of African researchers. Household food and health security can be ensured through breeding of disease free, higher yielding plants, mass propagation of better quality plants and crops with specific desirable characteristics. Plant biotechnology can therefore be an effective catalyst in commercializing crops, which can create jobs, earn foreign exchange and ensure a better quality of life for all.

\section{Notes:}

1 ORSTOM : Organisation de la Recherche Scientifique et Technologique d'Outre-Mer

${ }^{2}$ CIRAD : Centre de Cooperation Internationale en Recherche Agronomique pour le Développement

${ }^{3}$ BETCEN : Biotechnology Education and Training

Centre

${ }^{4}$ MIRCENs : Microbial Resources Centres

5 ISSAA : International Science for the Acquisition of Agri-Biotech Applications Ameri Center

${ }^{6}$ USAID : US Agency for International

Development

7 ABPS : Agricultural Biotechnology for

Sustainable Development

${ }^{8}$ KARI : Kenya Agricultural Research Institute

9 SADC : Southern African Development

Community

\section{References}

Brink, J.A. and Prior, B. (1998) The UNESCO BETCENMIRCEN Scientific Symposium: Proceedings of the Joint BETCEN - MIRCEN symposium, South Africa, March 1998.

James C. (1996). Chairman's Commentary. The First Decade of crop biotechnology. In: Advancing altruism in Africa. ISAAA Annual Report 1996.

James C. (1997). Progressing public-private sector partnership in International Agriculture Research and Development. In: ISAAA Briefs No 4, p. 1-32.

Lynam J.K. (1995). Building biotechnology research capacity in African NARS. In: Turning priorities into feasible programs. Proceedings of a Regional Seminar on planning priorities and policies for Agricultural Biotechnology, South Africa, April 1995, p. 33-40.

Massola, R. (1992) Plant biotechnology in sub-Saharan African Today. In: Plant Biotechnology for Developing Countries, eds Sasson, A. and Costarini, V. publ CTA/FAO, Netherlands

Michaelis, A.R. (1993) The Crisis in African Agriculture, Interdisciplinary Science Reviews. Vol 18:1-3

Nyira, Z.M. (1995). Need challenges and objectives for Biotechnology and agriculture in Africa. In: Turning priorities into feasible programs. Proceedings of a Regional Seminar on planning priorities and policies for Agricultural Biotechnology, South Africa, April 1995, p. 17-23. 
Persley G.J. (1992). Beyond Mendel's Garden: Biotechnology in Agriculture. In: Biotechnology enhancing research on tropical crops in Africa. CTA/IITA copublication,

p. 11-19.

\footnotetext{
${ }^{1}$ ORSTOM: Organisation de la Recherche Scientifique et Technologique d'Outre-Mer

${ }^{2}$ CIRAD : Centre de Cooperation Internationale en Recherche Agronomique pour le Développement

3 BETCEN : Biotechnology Education and Training Centre

${ }^{4}$ MIRCENs: Microbial Resources Centres

5 ISSAA : International Science for the Acquisition of Agri-Biotech Applications Ameri Center

${ }^{6}$ USAID : US Agency for International Development

7 ABPS : Agricultural Biotechnology for Sustainable Development

${ }^{8}$ KARI : Kenya Agricultural Research Institute

9 SADC : Southern African Development Community
}

Swaminathan M.S. (1995). Population, environment and food security. Issues in Agriculture, No 7. CGIAR, Washington DC.

Villalabos V.M. (1995). Biotechnology in agriculture: How to obtain its benefits while limiting risks. In: Induced mutations and molecular techniques for crop improvement. IAEA Publication, Austria, p. 477-486. 